\title{
Analysis of Consumer Perception towards Telecommunication Services
}

\author{
*Yasser Khan, Sayed Fayaz Ahmed, Zahid Mehmood, Muhammad Khalil Shahid, Muhammad Ibrahim \\ Institute of Communication Technologies, NWFP University of Engineering \& Technology, Peshawar, Pakistan \\ *yss_kh@yahoo.com
}

\begin{abstract}
The use of Telecommunication services has been strikingly increased in recent decade. Hence it has become crucial to investigate the reasons behind telecom usage patterns and understand factors playing an important role for perception of telecom services. These investigations are important for both consumers and telecommunication service provider in order to build a strong relationship towards better delivery of telecom services which may result in satisfied customer. The developed model of this research is consisting of five variables which have a lot of impact on perception of consumer towards adoption of telecom services. The results of this research have numbers of practical applications both for marketer and telecom service consumer.
\end{abstract}

Key Words: Consumer Perception, Value Added Services, Promotion, Relative Advantage

\section{Introduction}

Telecommunication is the main source of interaction between and among individuals and groups in order to exchange data both nationally and internationally within a matter of seconds and minutes. Telecommunication has been successful vanishing world border and made the world a global village (McLuhan, 1964) .The telecom sector is facing violent competition as it is passing through major changes of privatization and liberalization (Beard \& Hartmann, 1999). Telecommunication industry in Pakistan has been growing violently and updating it with global advancements. The following are the main types of "Value Added service offered by Mobile Phone Companies" in Pakistan.

Short Messaging Service: The kind of messaging to talk to acquaintance through cellular phone any time without using any computer.

Multi-Media Messaging Service: Instead of sending only text message, this service helps to share pictures, sound and video clips to intended.

Alerts Messages: This service provide updated headlines, game scores, horoscopes, sport results etc. by using traditional cellular phone by activating service.

E-mail and internet: We can send receive business or personal e-mails or browse any website on our mobile phone without going for computer when necessary.

Faxing Service: Facsimile service may be activating though normal mobile phone for sending or receiving fax. Online Payment services: Money may be easily transferred from one city to another in a matter of minutes For example easy paisa service launch by Telenor Pakistan, utility bill payment is possible while sitting indoor at home.

Mobile shopping: Different companies are offering shopping through purchasing online products or services. Entertainment services: To download music, ring tones songs from online server to mobile, this service full of joy especially for young customer.

Logo/Wallpaper: In order to decorate cell phone online, company logos, themes, expression (Artistic), and famous location.

Gaming services: Another application attracted by youngster is Java Games inside mobile and other mobile service include online directory enquires, voicemail, watching TV on cellular phone etc.

The growth of Telecommunication Industry is playing a pivotal role in building national economy development. The following figures show the Revenue and Teledensity of Telecommunication Services in Pakistan. 
Figure 1: Total Telecom Revenue according to Pakistan Telecom Authority

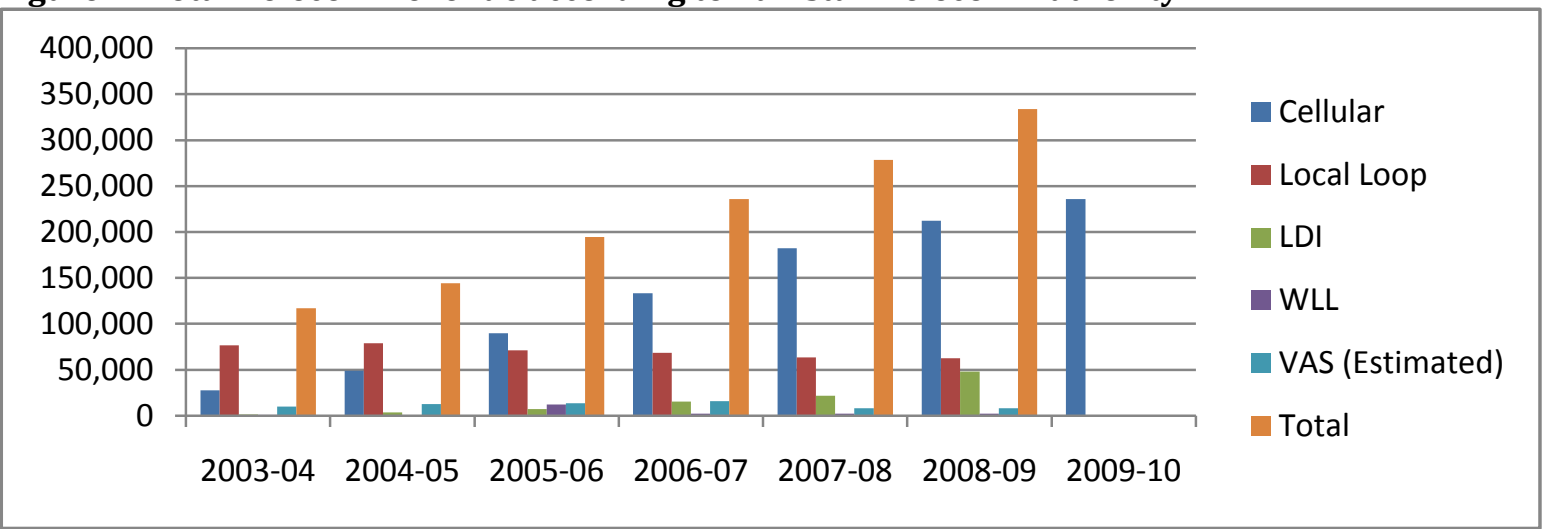

Figure 2: Total Teledensity (Fixed+WLL \& Mobile) in Pakistan

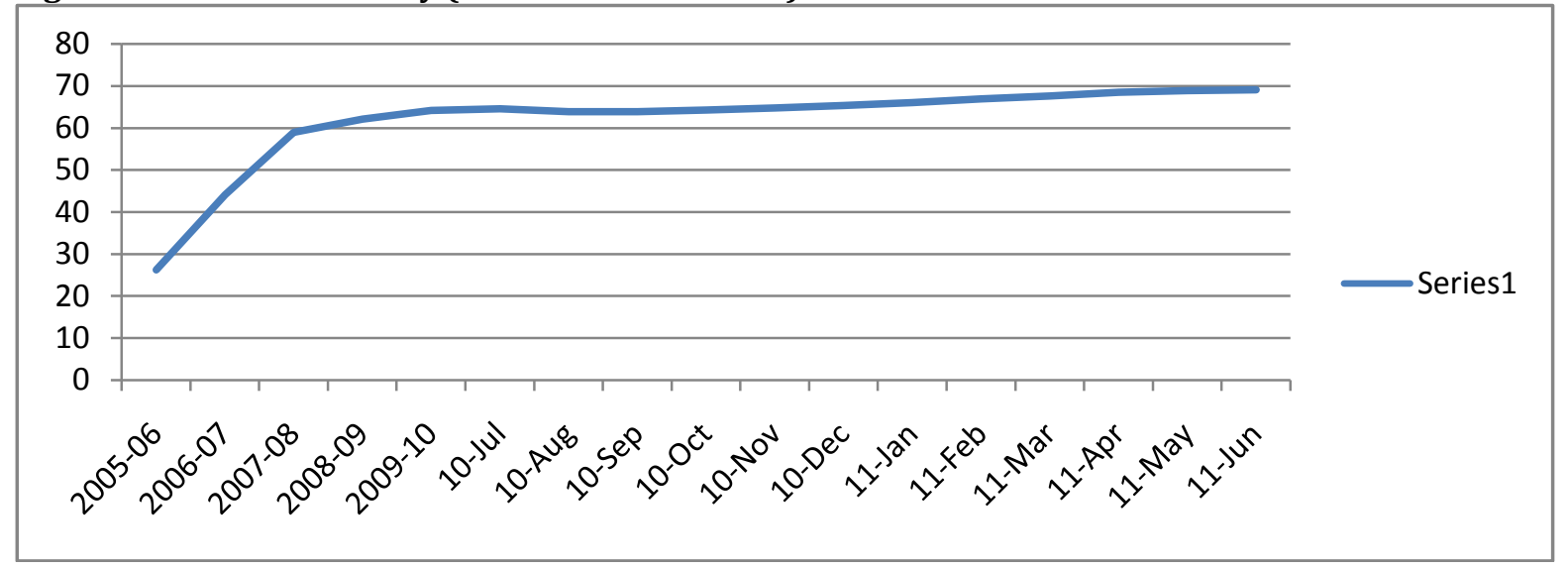

Pakistan has five major national and multinational players in providing GSM/Cellular services all over the country namely M/s Pakistan Mobile Company Limited (32.9 million subscribers), China Mobile Pakistan (10.9 million Subscribers), M/s Telenor Pakistan Limited (26.1 million Subscribers), M/s Warid Telecom Limited (18.1 million Subscribers) and M/s Ufone (20.4 million Subscribers). Pakistan Telecommunication Company limited is offering basic telephony, IP services, wireless and mobile markets and technologies, broadband markets and technologies. While Fixed-line subscriptions dropped down from a peak of 5.2 million in 2005-06 to 3.4 million in 2009-10 and broadband (DSL, HFC, WiMax, FTTH, EvDO and others) subscribers has exceed beyond 1,292,897 all over the Country.

This research is first timely initiated in Pakistan and before this attempt there is no research regarding to the research topic. This problem, on one side makes our research difficult to conduct due to lack of such studies to have with us for reference but on the other side makes it more and more valuable, which is not only necessary for the research but has provide a strong aim and claim to conduct due to its need and importance. The research is carried out with the following objectives.

- The buying behaviors of Telecom services can be predicted through factors influencing marketing process.

- To determine customer preferences towards service in order to upgrade telecom value added services.

- To study influences of Promotion, Quality of Service, User friendly, Relative advantages and Enjoyment (Perceived) on consumer perception towards telecom services.

- To analyze Pakistan Telecom Market and customer satisfaction in Telecom Sector.

- To design a model for analysis of consumer perception towards Telecom services. 


\section{Literature Review}

Promotion: Product offering can be best communicated through promotion /advertisement and considered to be a one of most important medium (Rowley, 1998). All companies are using promotion for introduction of new product in a market (Kotler, Armstrong, Saunders, Wong, 1999). In order to compel potential customer to purchase new product or service, promotion is considered to best medium for communication. This is providing awareness about new product/services and company as well (Root, 1994). Promotional activities has main objective to launch a new product or service in the market to target customer, devise strategy to compete other product, improve sales to increase market share and create need for potential customer.

Advertisement and promotional activities are considered to be stimuli in order to receive responses of potential customer in the form of increase in sale. The promotion is consisting of discounts, displaying of product at market, distribute samples among people, contests, premiums etc. The promotional activities bring more fruits if these are provided from time to time and result in better sale impact (Kotler, Armstrong, Saunders, Wong, 1999). The activities become more effective if they are planned systematically and well organized according to best practices. Well planned promotional also helpful for selling of those products and services whose customer are not willing to accept it. The following assumption has been made for our research.

Hypothesis 1: Promotion has a direct positive effect on consumer perception towards adoption of Telecommunication service.

Quality of Service: Qos of service has been proved successful to create competitive advantage to increase sales of product and services. Telecommunication has been successful to win profitable and loyal customer by improving Quality of services (Leisen and Vance, 2001) By increasing service quality and getting feedback from satisfied customer is helpful for telecommunication service manager to enhance company sales through better service delivery system (Sirikit \& Johson, 2002) Product attributes plays a substantial role for economics and marketing especially in field of telecommunication which is considered to two very important pillars in operational management (Wang \& Lo, 2002). Consumer will not prefer low price product or service at the cost of QoS (Boyer \& Hult, 2005). Consumer expectation must meet or exceed customer expectation shows the extent of telecom service quality (Wal, 2002). China telecommunication sector gain a great boom due to better service quality, customer satisfaction and consumer value (Wang \& Lo, 2002).

Service quality is the extent which repeats the buying behavior of loyal customer which is adopted during the consumption of that product and service. Extensive studies have been conducted to understand perception of quality is mind set of potential customer. This must not be consider as first impression phenomena (Crosby, 1979) The Quality of service must not mistaken for comfort, glitter or weight of substance (Crosby, 1979) Quality of service is not easily understand and expressed by consumer (Takeuchi and Quelch, 1983). To determine clarification of quality is problematic for researchers (Monroea and Krishnan, 1983), the problem towards QoS become more sever if actually concept is ignored and one dimension is taken to capture the idea (Jacoby, Olson, and Haddock, 1973). There is a lot of research studies to determine return on investment and shares of market which may help to lower the cost of products and services (Anderson and Zeithaml, 1984) of the consumer are asked for quality of products and services which in turn create awareness among consumers (Rabin, 1983). Davis (1989) defines user friendly is actually a perception by itself to determine consumer believe about a system would be free of effort. If consumer establish an idea for ease of use they are more probable to accept the product (Dahlberg, Mallat \& Penttinen, 2003).

The following hypothesis has been proposed to further elaborate the quality of service in telecommunication sector towards consumer perception:

Hypothesis 2: Quality of Service has a direct positive effect on consumer perception towards adoption of Telecommunication service.

User Friendly: It is a common sense that people prefers that services which is of many uses and which offers a lot of benefits and usefulness to them. The user friendly product and service doesn't require extra skills/efforts on the part of consumer so easily perceived and adopted (Tornatzky \& Klein, 1982). Innovative 
complex services are perceived less than user friendly services Hence services which are easy to use will adopt easily (Rogers \& Shoemaker, 1971). The same phenomenon is studied and observed easy applications are frequently adopted by consumers compare to complex one (Davis, Bagozzi, \& Warshaw, 1989).

The probability to adopt easily understandable services is greater than difficult one as it does not require many efforts on the part of consumer which raise the chances to use. In addition to mentioned research (Ma \& Liu, 2004; Davis, 1989; Venkatesh, 2000) further studied the attitude of customer to purchase and use Telecommunication Services which is directly link with ease of use and further acceptance among end user. The above literature survey summarizes that consumers will like to use those telecommunication services which have more benefits and seems to be friendlier to them in their uses and much easy in their adaptation.

The below hypothesis regarding to this variable was developed and was included in the research. Hypothesis 3: Ease of Use has a direct positive effect on consumer perception towards adoption of Telecommunication service.

Relative Advantage: There are a lot of same services, telecommunication service provider offers its customers. Each day comes with hundreds of new advantages of these services. Now it comes to the consumers whom, why and which services they should use and adopt (Rogers, 1995). The phenomenon is defined as to perceive and adopt new service better than the service it supersedes. Hence relative advantage is conceived to best indicator of its acceptance among customers and directly proportional to adoption of new services. People always adopt that services which has more relative advantages as compare to competitors services (Agarwal \& Parshad, 1999). Relative advantage has also a lot of influence over attitude of the customers which further shape their perception towards adoption of telecom services (Rogers, 1983). The above lines compel us to derive the assumptions in the following shape.

Hypothesis 4: Relative Advantage has a direct positive effect on consumer perception towards adoption of Telecommunication service.

Enjoyment: Enjoyment is considered to one of importance factors which apply a greater impact to adopt innovative telecommunication services among user (Hoflich \& Rossler, 2001). While using telecom services increase intrinsic rewards will further enhance enjoyment in and raise the chances to adopt and use the service. In addition to this one more research has studied that perceived enjoyment impacts a lot for experimental services like there is chance to win or lose a situation which provide fun and relaxation e.g. gaming (Lexhagen, Nysveen, \& Hem, 2005). The phenomenon is true in low information services. In contrast, high information services perceived enjoyment influence negatively the consumer perception towards telecom services. Low information intensive services may also require immense amount of data to develop and process. Without taking any performance into consideration, using computer is source of enjoyment for potential consumer (Davis, 1989). The below hypothesis has derived from this literature.

Hypothesis 5: Enjoyment (Perceived) has a direct positive effect on consumer perception towards adoption of Telecommunication service.

Figure 3: Structural Model

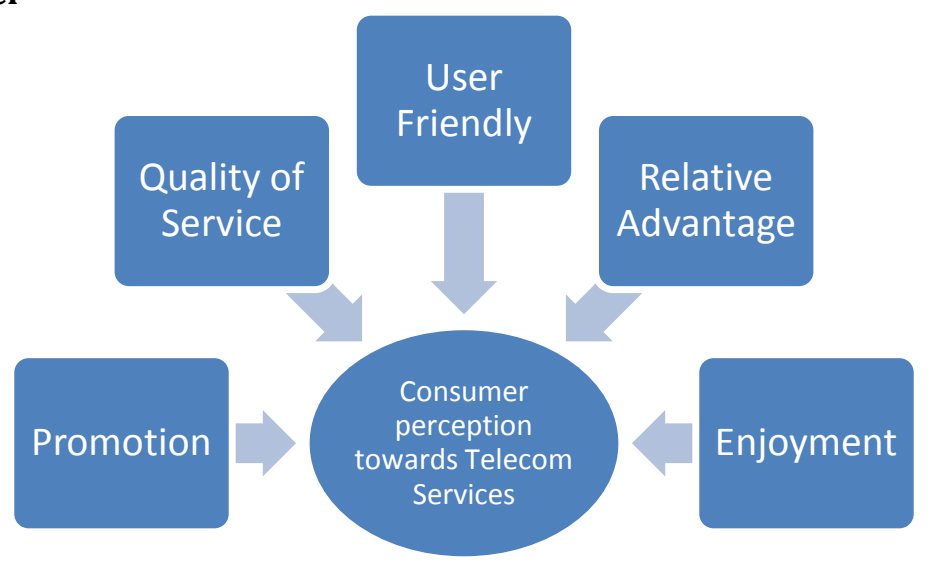




\section{Research Methodology}

The research regarding has been conducted on primary data. In order to fulfill this objective a questionnaire was developed and 05 questions on each variable were recorded. The questionnaire is consisting of introduction of topic and reason of research. This is further made ensure to all respondents that their information would be kept confidential. Here Likert Scale is used with choices of Strongly Agree, Agree, Neutral, Disagree and Strongly Disagree.

Research Design: The research study is consisting of hypotheses testing to investigate the relationships among different variables affecting consumer perception towards telecom services. Before providing questionnaire to each respondent an introduction session was carried out regarding subject mentioned matter. Random sampling method was used in the survey to better deal research work and respondents are consist of all different races, color ,sex and geography . The following assumptions were kept in mind during conducting the survey.

- The area selected is assumed to represent M/s Pakistan Mobile Company, China Mobile, M/s Telenor Pakistan Limited, M/s Warid Telecom Limited and M/s Ufone and Pakistan Telecommunication Company limited.

- Data collected are assumed to be bias free from side of respondents.

- An unbiased survey has been conducted for whole research without any influence of any factor which can deviate research result.

The research is design on testing hypothesis assumed in afore mentioned part of report. There are five independent variables and one dependant variables are connected with a relationship. Depend upon these variables questionnaire is design, hand over and given full freedom to respondents to select either of choice from given tables against each question. It is further tried to ensure that each gender, age-group and profession equally participate in survey. As it is academic research which lack funding and time, hence out of 230 distributed questionnaire only 186 responses received in completed form. The rest of feedbacks were collected in some form incomplete. Hence the response rate is noted as $80 \%$.

Sampling: The area selected is assumed to represent M/s Pakistan Mobile Company, China Mobile Pakistan, M/s Telenor Pakistan Limited, M/s Warid Telecom Limited and M/s Ufone and Pakistan Telecommunication Company limited. Data collected are assumed to be bias free from side of respondents. An unbiased survey has been carried out to avoid any deviation in findings. The sampling method used in this research analysis is simple random sample in order to ensure that equal opportunity is given to all potential respondents for both sexes, age-group, demographic, geography, domicile and language. Every possible effort was made that both sexes equally participate in study to ensure transparency and avoid any biasness in result. Hence gender wise responses received are as follow in table No.01, age wise distribution in table No. 02 and Profession wise distribution in table No. 3.

Table 1: Gender wise Distribution

\begin{tabular}{llllll}
\hline & & Frequency & Percent & Valid Percent & Cumulative Percent \\
\hline Valid & Male & 144 & 77.4 & 77.4 & 77.4 \\
& Female & 42 & 22.6 & 22.6 & 100.0 \\
& Total & 186 & 100.0 & 100.0 & \\
\hline
\end{tabular}

Table 2: Age wise Distribution

\begin{tabular}{llllll}
\hline & & Frequency & Percent & Valid Percent & Cumulative Percent \\
\hline Valid & $10-20$ & 28 & 15.1 & 15.1 & 15.1 \\
& $20-40$ & 96 & 51.6 & 51.6 & 66.7 \\
& $>40$ & 62 & 33.3 & 33.3 & 100.0 \\
& Total & 186 & 100.0 & 100.0 & \\
\hline
\end{tabular}


Table 3: Profession wise Distribution

\begin{tabular}{llllll}
\hline & & Frequency & Percent & Valid Percent & Cumulative Percent \\
\hline Valid & Student & 7 & 3.8 & 3.8 & 3.8 \\
& House Wife & 22 & 11.8 & 11.8 & 15.6 \\
& Public Service & 31 & 16.7 & 16.7 & 32.3 \\
& Private Service & 96 & 51.6 & 51.6 & 83.9 \\
& Business & 30 & 16.1 & 16.1 & 100.0 \\
Total & 186 & 100.0 & 100.0 & \\
\hline
\end{tabular}

\section{Results}

This chapter explains the analysis of the data. The data was analyzed with SPSS tools in order to obtain some useful results. In order to carry out reliability test we need to have reliability statistic which is determine by Cronbach's Alpha is calculated as 0.901 for total 6 items. The following lines present the analysis and results of the research.

Gender wise Statistics: These statistic shows variables include in the research has no significant value for either gender as show in below mentioned table. It means that male and female have similar value and perception for a telecom services adaptation.

Table 4: ANOVA Analysis for Gender

\begin{tabular}{llllll}
\hline & Sum of Squares & Df & Mean Square & F & Sig. \\
\hline Between Groups & .153 & 1 & .153 & .311 & .578 \\
Within Groups & 90.651 & 184 & .493 & & \\
Total & 90.805 & 185 & & .632 & .428 \\
Between Groups & .202 & 1 & .202 & & \\
Within Groups & 58.711 & 184 & .319 & .136 & .713 \\
Total & 58.913 & 185 & & & \\
Between Groups & .044 & 1 & .044 & .138 & .710 \\
Within Groups & 59.482 & 184 & .323 & & \\
Total & 59.526 & 185 & & .000 & .992 \\
Between Groups & .030 & 1 & .030 & & \\
Within Groups & 39.354 & 184 & .214 & & \\
Total & 39.383 & 185 & & .298 & \\
Between Groups & .000 & 1 & .000 & & \\
Within Groups & 157.685 & 184 & .857 & & \\
Total & 157.685 & 185 & & & \\
Between Groups & .130 & 1 & .130 & & \\
Within Groups & 80.319 & 184 & .437 & & \\
Total & 80.449 & 185 & & & \\
\hline
\end{tabular}

Age Analysis: The statistic for different age group was analyzed as follow. There is significance found for Quality of Service, User friendly and enjoyment for consumer perception towards telecom services while no significance for rest of two variables i.e. Promotion and Relative Advantage. In other words different respondents have different view about the attributes like Quality of Service, user friendly and enjoyment while the rest posses no difference for them, when they are categorized in age groups. 
Table 5: ANOVA Analyses for Age

\begin{tabular}{llllll}
\hline & Sum of Squares & Df & Mean Square & F & Sig. \\
\hline Between Groups & 2.292 & 2 & 1.146 & 2.369 & .096 \\
Within Groups & 88.513 & 183 & .484 & & \\
Total & 90.805 & 185 & & 4.011 & .020 \\
Between Groups & 2.474 & 2 & 1.237 & & \\
Within Groups & 56.439 & 183 & .308 & & \\
Total & 58.913 & 185 & & 3.854 & .023 \\
Between Groups & 2.406 & 2 & 1.203 & & \\
Within Groups & 57.121 & 183 & .312 & .946 & .390 \\
Total & 59.526 & 185 & & & \\
Between Groups & .403 & 2 & .202 & & \\
Within Groups & 38.980 & 183 & .213 & & \\
Total & 39.383 & 185 & & & \\
Between Groups & 5.054 & 2 & 2.527 & .030 & \\
Within Groups & 152.631 & 183 & .834 & & \\
Total & 157.685 & 185 & & & \\
Between Groups & .132 & 2 & .066 & & \\
Within Groups & 80.317 & 183 & .439 & & \\
Total & 80.449 & 185 & & & \\
\hline
\end{tabular}

Profession: The statistic according to different profession has all variable found with significance values. This means that needs, value and demands for type and attribute of telecom services change from profession to profession as shown in the following table.

Table 6: ANOVA Analysis for Profession

\begin{tabular}{|c|c|c|c|c|c|c|}
\hline & Sum of Squares & Df & Mean & Square & $\mathbf{F}$ & Sig. \\
\hline Between Groups & 26.734 & 4 & 6.684 & & 18.881 & .000 \\
\hline Within Groups & 64.070 & 181 & .354 & & & \\
\hline Total & 90.805 & 185 & & & & \\
\hline Between Groups & 9.248 & 4 & 2.312 & & 8.426 & .000 \\
\hline Within Groups & 49.664 & 181 & .274 & & & \\
\hline Total & 58.913 & 185 & & & & \\
\hline Between Groups & 14.821 & 4 & 3.705 & & 15.001 & .000 \\
\hline Within Groups & 44.706 & 181 & .247 & & & \\
\hline Total & 59.526 & 185 & & & & \\
\hline Between Groups & 5.242 & 4 & 1.311 & & 6.948 & .000 \\
\hline Within Groups & 34.141 & 181 & .189 & & & \\
\hline Total & 39.383 & 185 & & & & \\
\hline Between Groups & 15.710 & 4 & 3.928 & & 5.007 & .001 \\
\hline Within Groups & 141.975 & 181 & .784 & & & \\
\hline Total & 157.685 & 185 & & & & \\
\hline Between Groups & 11.519 & 4 & 2.880 & & 7.562 & .000 \\
\hline Within Groups & 68.930 & 181 & .381 & & & \\
\hline Total & 80.449 & 185 & & & & \\
\hline
\end{tabular}


Correlation Analysis: (Among variable Promotion, Quality of Service, User friendly/Ease of Use, Relative Advantage and Enjoyment) with Consumer Perception towards Telecom Service:-

In order to determine consistency among different variable towards consumer perception, the data is analyze for correlation which result the following lines and values. The details of correlation analysis is given in the below correlation Matrix Table which highlights the value of significance from a range of 0.05 to 0.01.Following table also shows formulation of hypothesis.

H1: Promotion has a direct positive effect on consumer perception towards adoption of Telecommunication service:

The relationship between promotion of a telecommunication service and its adaptation is positive and significant with values of $\left(.310\left(^{* *}\right), \mathrm{P}=.000\right)$. Hence there exists significant positive relationship between Promotion and consumer perception.

H2: Quality of Service has a direct positive effect on consumer perception towards adoption of Telecommunication service:

The values for the relationship between quality of service and its adaptation has value of $(.547(* *), \mathrm{P}=.000)$. Hence there exists significant positive relationship between QoS and consumer perception.

H3: User friendly/Ease of Use has a direct positive effect on consumer perception towards adoption of Telecommunication service:

Ease of use or User friendly is connected with the values of $\left(.384\left(^{* *}\right), \mathrm{P}=.000\right)$ with adaptation of a telecom service. Hence there exists significant positive relationship between User friendly and consumer perception.

H4: Relative Advantage has a direct positive effect on consumer perception towards adoption of Telecommunication service:

There exists significant positive relationship between Relative Advantage and consumer perception represented in the below table with the values of $\left(.508\left(^{* *}\right), \mathrm{P}=.000\right)$. This clarifies our assumption.

H5: Enjoyment (Perceived) has a direct positive effect on consumer perception towards adoption of Telecommunication service.

The values of correlation analysis are (.676(**), $\mathrm{P}=.000)$ for Enjoyment (Perceived) and consumer perception. Hence there exists significant positive relationship between.

Table 7: Correlations analysis

\begin{tabular}{|c|c|c|c|c|c|c|}
\hline & $\mathrm{P}$ & QoS & UF & RA & E & $\mathrm{AT}$ \\
\hline Pearson Correlation & 1 & & 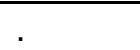 & & & \\
\hline Sig. (2-tailed) & & & & & & \\
\hline $\mathrm{N}$ & 186 & & & & & \\
\hline Pearson Correlation & $.767(* *)$ & 1 & & & & \\
\hline Sig. (2-tailed) & .000 & & & & & \\
\hline $\mathrm{N}$ & 186 & 186 & & & & \\
\hline Pearson Correlation & $.695(* *)$ & $.819\left(^{* *}\right)$ & 1 & & & \\
\hline Sig. (2-tailed) & .000 & .000 & & & & \\
\hline $\mathrm{N}$ & 186 & 186 & 186 & & & \\
\hline Pearson Correlation & $.494(* *)$ & $.781(* *)$ & $.684(* *)$ & 1 & & \\
\hline Sig. (2-tailed) & .000 & .000 & .000 & & & \\
\hline $\mathrm{N}$ & 186 & 186 & 186 & 186 & & \\
\hline Pearson Correlation & $.615\left(^{* *}\right)$ & $.791(* *)$ & $.810(* *)$ & $.679\left(^{* *}\right)$ & 1 & \\
\hline Sig. (2-tailed) & .000 & .000 & .000 & .000 & & . \\
\hline $\mathrm{N}$ & 186 & 186 & 186 & 186 & 186 & \\
\hline Pearson Correlation & $.310\left(^{* *}\right)$ & $.547(* *)$ & $.384(* *)$ & $.508(* *)$ & $.676\left(^{* *}\right)$ & 1 \\
\hline Sig. (2-tailed) & .000 & .000 & .000 & .000 & .000 & \\
\hline $\mathrm{N}$ & 186 & 186 & 186 & 186 & 186 & 186 \\
\hline
\end{tabular}

** Correlation is significant at the 0.01 level (2-tailed) 
Regression Analysis: As shown in the following regression table, the results calculated through SPSS tool are $\mathrm{R}$-Square $=0.585$, F-Value $=50.835$.The result shows that this research has significance $(\mathrm{P}-\mathrm{Value}<0.05)$ which interpret a firm relationship between all dependant and dependant variables. The model is tested for individual basis hence strong significance found for all variables. All dependant variables taken in research has varying degree of importance found for consumer perception towards telecom services?

Table 8: Regression Coefficients

\begin{tabular}{llllllll}
\hline Model & B & Std. Error & T-Statistics & Sig. & R-Square & F & P-Value \\
\hline (Constant) & 2.066 & .279 & 7.397 & .000 & .585 & 50.835 & $0.000(\mathrm{a})$ \\
P & .149 & .075 & 1.987 & .048 & & & \\
QoS & .452 & .142 & 3.192 & .002 & & & \\
UF & -.724 & .113 & -6.437 & .000 & & & \\
RA & .131 & .86 & 1.729 & .043 & & & \\
E & .650 & .064 & 10.198 & .000 & & & \\
\hline
\end{tabular}

a. Predictors: (Constant), E, P, RA, UF, QoS

b. Dependent Variable: CP

\section{Conclusion}

All variables Promotion, Quality of Service, User friendly, Relative Advantage and Enjoyment have positive relationship with consumer perception. Hence it is concluded from the research that all these variables must be considered in designing and launching of industrial product and services to get good match between consumer and marketers. The regression analysis shows the significance of all variable in the model. Hence the model design is of high importance and there exist significant correlation which strongly recommends the intention of consumer perception towards telecom services. Relative advantage in the research study is very important variable, it represents consumer in Pakistan positively perceived the telecom services.

Telecom services reduces overall cost, time of operation for contacting overseas partner, provide opportunity in order to communicate the people around the world. The online payment services offered by Telecom Company may help to expand business in short span of time. The role of telecom services has become substantial than before in term of social networking and relations. The dramatic popularity of social networking sites are experienced where consumers are sharing their profiles, pictures and post comments about every day events which are further categorize according to age and relationship and causing engagements on social perspectives. According to one studies by Market Research Group, consumer at an age of 15 to 24 year old in United Kingdom 81\% of Short Messaging Service are sent for social arrangements while $42 \%$ are use for flirts.

Due to introduction of IPTV and internet TV, consumer ability to access the music, drama and movies has been increased they have not seen before. Besides concentrating on entertainment events, a lot of people are using it to understand current affairs and political news.

Recommendations: The following points are recommended for telecom service providers and researchers.

- Telecom service providers must consider the above discussed attributes, when they want to offer a telecom service their consumers.

- Telecom service providers should provide individual services to different groups of consumers. E. g. they should offer service to a group according to their needs and demand.

- The Telecom service attributes like Promotion, Quality of Service, User friendly/Ease of Use, Relative Advantage and Enjoyment is directly proportional to the adaptation of telecom service, and service providers need to increase them to the best possible value, to make their services available and easy approachable and acceptable to their consumers.

- Future researches can take help from this study, as this research is first timely created and conducted in Pakistan, and will provide them to analyze the product of telecom service providers.

- Future researchers can take this research into consideration when they wish to offer a new service to its consumers or launch a new product. 


\section{References}

Agarwald, R. \& Prasad, J. (1999). Are individual differences germane to the acceptance of new information technologies? Decision Sciences, 30(2), 361-391.

Anderson, C. and Zeithaml, P. C. (1984). Stage of the Product Life Cycle, Business Strategy, and Business Performance. Academy of Management Journal, 27, 5-24.

Rabin, J. H. (1983). Accent Is on Quality in Consumer Services This Decade. Marketing News, 17(4), 12.

Beard, C. and Hartmann, R. (1999). European and Asian Telecoms - Their Role in Global Sustainable Development. European Business Review, 99(1), 42-54.

Boyer, K. K. and Hult, G. T. (2005). Customer Behavior in an Online Ordering Application: A Decision Scoring Model. Decision Sciences, 36(4) 569-598.

Crosby, P. B. (1979). Quality is Free: The Art of Making Quality Certain, New York: New American Library.

Dahlberg, T., Mallat, N., \& Penttinen, E. (2002). Value of Electronic and Mobile Payment Solutions to Consumers - Results of a Focus Group Research (Working papers): Helsinki School of Economics.

Davis, F. D. (1989). Perceived usefulness, perceived ease of use, and user acceptance of information technology. MIS Quarterly, 9, 319-340.

Davis, F. D., Bagozzi, R. P., \& Warshaw, P. R. (1989). User acceptance of computer technology: A comparison of two theoretical models. Management Science, 35, 982-1002.

De Brentani, U. (1991). Success factors in developing new business service. European Journal of Marketing, 25, 33- 59.

Höflich, J. R. \& Rössler, P. (2001). Mobile schriftliche kommunikation oder: E- mail für das handy. Medien \& Kommunikationswissenschaft, 49, 437-461.

Jacoby, J., Jerry C. O., and Rafael A. H. (1973). Price, Brand Name and Product Composition Characteristics as Determinants of Perceived Quality. Journal of Applied Psychology, 55(6), 570-579.

Johnson, W. C. and Sirikit, A. (2002). Service Quality in the Thai Telecommunication Industry: A Tool for Achieving a Sustainable Competitive Advantage. Management Decision, 40(7) 693-701.

Kotler, P., Armstrong, G., Saunders, J., \& Wong, V., (1999). Principles of Marketing, Second Edition, Prentice Hall Inc. New York.

Lexhagen, M., Nysveen, H., \& Hem, L. E. (2005). Festival coordination: An exploratory study on intention to use mobile devices for coordination of a festival. Event Management, 9, 133-146.

Leisen, B. \& Vance, C. (2001). Cross-national Assessment of Service Quality in the Telecommunication Industry: Evidence from the USA and Germany. Managing Service Quality, 11(5), 307-317.

Ma, Q., \& Liu, L. (2004). The technology acceptance model: A Meta analysis of empirical findings. Journal of Organizational and End User Computing, 16(1), 59-72.

McLuhan, M. (1964). Understanding Media: The Extensions of Man, New York: Mentor in Levinson.

Monroe, K. B. and Krishnan, R. (1983). The Effect of Price on Subjective Product Evaluations. Blacksburg: Virginia Polytechnic Institute, working paper.

Paul (2000). McLuhan and Media Ecology, Proceedings of Media Ecology Association, available at: http://www.media-ecology.org/publications/proceedings/v1/levinson01.pdf, Accessed on: 12-12-11.

Rogers, E. M. (1983). Diffusion of Innovations. The Free Press, London.

Rogers, E. M., \& Shoemaker, F. F. (1971). Communication of Innovations: A Cross-Cultural Approach. Free Press, New York, NY

Rogers, E. M. (1995). Diffusion of Innovations (4th ed.). New York: Free Press.

Rowley, J. (1998). Promotion and Marketing Communications in the Information Marketplace. Library Review, 47(8), 383-387.

Root, R. R. (1994), Entry Strategies for International Markets, McMillan Inc. New York.

Takeuchi, H. \& John A. Q. (1983). Quality Is More Than Making a Good Product. Harvard Business Review, 61, 139-145.

Tornatzky, J. G., \& Klein, K. J. (1982). Innovation characteristics and innovation adoption implementation: A Meta analysis of findings. IEEE Transactions on Engineering and Management, 29(1), 28-45.

Venkatesh, V. (2000). Determinants of perceived ease of use: Integrating control, intrinsic motivation, and emotion into the technology acceptance model. Information Systems Research, 11(4), 342-365.

Wang, Y. and Hing-Po, L. (2002). Service Quality, Customer Satisfaction and Behavior Intentions: Evidence from China's Telecommunication Industry. Info, 4(6), 50-60.

Wal, R. W. E., Van der, P. A., \& Bond, C. (2002). Service quality in a cellular telecommunications company: A South African experience. Managing Service Quality, 12(5), 323-335. 